\title{
The characteristics of oxygen concentration and the role of correction factor in real-time GI Breath Test
}

Siu Man Lee, Imogen HE Falconer, Trudi Madden, Peter O Laidler

Healthcare Engineering \& GI Physiology

Department of Medical Physics \& Bioengineering, Royal United Hospitals NHS FT, UK

$23^{\text {rd }}$ February 2021

\section{ABSTRACT}

A high quality end-expiratory breath sample is required for a reliable Gl breath test result. Oxygen $\left(\mathrm{O}_{2}\right)$ concentration in the breath sample can be used as a quality marker. This study investigated the characteristics of oxygen concentration in breath sample and the issues with using a correction factor in real-time breath test. The results indicated $95.4 \%$ of 564 patients were able to achieve an $\mathrm{O}_{2}$ concentration below $14 \%$ in their end-expiratory breath. A further 293 samples were studied and revealed that the distribution of $\mathrm{O}_{2}$ concentration was between $16.5 \%$ and $9.5 \%$. Applying a correction factor to predict the end-expiratory $\mathrm{H}_{2}$ and $\mathrm{CH}_{4}$ values led to an average error of $-36.4 \%$ and $-12.8 \%$ respectively. The correction factor algorithm based on limiting $\mathrm{O}_{2}$ at $14 \%$ would have resulted in false negative result for $50 \%$ of the positive cases. This study has also indicated the continuous $\mathrm{O}_{2}$ measurement is essential to ensure breath sample quality by preventing secondary breathing during real-time breath collection.

\section{KEYWORDS}

Breath test, end-expiratory breath, oxygen concentration, real-time measurement 
medRxiv preprint doi: https://doi.org/10.1101/2020.10.22.20213876; this version posted February 23,2021 . The copyright holder for this preprint (which was not certified by peer review) is the author/funder, who has granted medRxiv a license to display the preprint in

All rights reserved. No reuse allowed without permission.

\section{INTRODUCTION}

Breath test (BT) has been widely used as a diagnostic tool to identify conditions related to the Gastrointestinal (GI) tract. It is a non-invasive, low cost and functional diagnostic test. Depending on the type of carbohydrate administered during the test, it can provide useful information to assist diagnosis of conditions like lactose mal-digestion, using lactose, and Small Intestine Bacterial Overgrowth (SIBO), using glucose or lactulose. The bacterial colonies in the digestive tract metabolise the carbohydrate and produce hydrogen or methane. These trace gases are absorbed in the intestine, returned to the lungs and equilibrated with air in the alveoli. The concentration of these trace gases can then be detected in the breath.

However, although GI breath test is simple and well tolerated by patients, there are a number of uncertainties within the test result, mainly related to the quality of the breath samples collected as well as the patient preparation procedures. Such uncertainties can adversely affect the accuracy of the result. There are criticisms among clinicians who do not consider Hydrogen Breath Test (HBT) as a reliable diagnostic test $[1,2]$. Significant effort has been spent on standardising and refining the protocol in order to make the test more reliable, such as the Rome Consensus and North American Consensus $[3,4]$. A common understanding in the test protocol is that alveolar air or end-expiratory breath is critical to the accuracy of the test result [5-10]. In addition, it is well-known that methane can be produced instead of hydrogen when the patient possess methanogenic bacteria that converts hydrogen $\left(\mathrm{H}_{2}\right)$ to methane $\left(\mathrm{CH}_{4}\right)$. It has been estimated between $5 \%-15 \%$ of the population is affected [11].

Traditionally, only $\mathrm{H}_{2}$ concentration is measured. This may be due to the availability of a cost-effective detection system with precision down to part-per-million ( $\mathrm{ppm}$ ). More modern breath analysers are now commercially available and they are able to concurrently measure both $\mathrm{H}_{2}$ and $\mathrm{CH}_{4}$. This equipment often includes measurement of oxygen $\left(\mathrm{O}_{2}\right)$ or carbon dioxide $\left(\mathrm{CO}_{2}\right)$ as a quality indicator of the breath sample. The rational that defined the $\mathrm{CO}_{2}$ concentration of an end-tidal breath as $5 \%$ was published in the seventies [12]. This value was widely adopted in subsequent research in breath tests. $\mathrm{O}_{2}$ concentration of alveolar air was approximated as $14 \%$ but it was estimated mathematically using the alveolar gas equation [13]. This equation has been widely used in studies on sustainable breathing, such as safety limit for hypoxemia [14]. However, the application of the alveolar gas equation can be limited by the conditions that the equation was derived. It may not be applicable to the single and maximum exhalation in Gl breath test conditions.

The main technologies employed in the breath analysers are gas chromatography, electro-chemical sensing and opto-electronic sensing. There are a range of different types of analyser designs commercially available. However, they can be categorised into either Point-of-Care (POC) systems or laboratory systems. POC analysers can take either real-time measurement or can use a collection bag to collect breath sample from patients. Real-time measurement collects a breath sample and concurrently analyses the trace $\mathrm{H}_{2} / \mathrm{CH}_{4}$ concentration so no sample storage is required. It avoids volume normalisation, sample contamination and storage issues which can affect its accuracy. Laboratory based analysers require breath samples to be collected in a vessel and the batch of breath samples will be analysed at the same time.

This study demonstrated the characteristics of end-expiratory oxygen concentration in breath sample during real-time $\mathrm{Gl}$ breath measurement. The results also illustrated the issues with the correction factor based on $\mathrm{O}_{2}$ concentration in the breath that may lead to an incorrect diagnostic result. The findings in this study may be used to guide future development of $\mathrm{Gl}$ breath analysers and may help to reduce uncertainties in the GI breath test result. It may also help to refine the breath collection protocol and further improve the accuracy of the test result. 
medRxiv preprint doi: https://doi.org/10.1101/2020.10.22.20213876; this version posted February 23, 2021. The copyright holder for this preprint (which was not certified by peer review) is the author/funder, who has granted medRxiv a license to display the preprint in All rights reserved. No reuse allowed without permission.

\section{METHODS}

The clinical data in this study was collected via an audit of Combined $\mathrm{H}_{2} / \mathrm{CH}_{4}$ Breath Test (CBT) results at the Royal United Hospitals Bath NHS Foundation Trust, UK. The patients had followed the standard preparation protocol included a fasting period of 12 hours prior to the test as described in the North American Consensus [3].

Breath samples were collected in real-time measurement. In order to obtain an end-expiratory breath sample, every patient undergoing CBT test followed a strict instruction during each breath sample collection. Patients were asked to breathe in normally; hold their breath for 5 seconds and breathe out completely. When the patient was breathing into the analyser, the flow-rate was strictly monitored and maintained at optimum level as specified by the manufacturer. There was no noticeable leakage around the mouth piece and nose while the patients were encouraged to breathe out completely.

A breath sample was taken every 20 minutes, and the hydrogen, methane, and oxygen level, as well as the correction factor from the breath analyser were recorded.

CBT was performed by the GastroCH${ }_{4} \mathrm{ECK}$ Gastrolyzer (Version 1) (software version: V11.0), manufactured by Bedfont Scientific Ltd. UK, see Figure 1. This instrument provides continuous realtime measurement of $\mathrm{H}_{2}, \mathrm{CH}_{4}$ and $\mathrm{O}_{2}$ concentration, in parts per million (ppm), during an episode of breath sample collection. It also provides a ratiometric correction factor according to the $E E O_{2}$. Typically in a breath collection episode, the hydrogen and methane concentration will rise from zero; while the oxygen concentration will drop from the atmospheric concentration (20.9\%) to ${ }_{E E O} \mathrm{O}_{2}$ which is typically below $14 \%$. The manufacturer regards the ideal $E E O_{2}$ as $13.9 \%(<14 \%)$ [15]. The $E E O_{2}$ value is used to produce the ratiometric Correction Factor (CF). The CF is applied to the $\mathrm{H}_{2}$ and $\mathrm{CH}_{4}$ measurement and attempts to compensate for the non-expiry breath sample. The predicted hydrogen $\left(\mathrm{CF} \mathrm{H}_{2}\right)$ and predicted methane $\left(\mathrm{CFCH}_{4}\right)$ values are expressed as the product of the actual $\mathrm{H}_{2} / \mathrm{CH}_{4}$ measurement and the $\mathrm{CF}$. When the $\mathrm{EEO}_{2}$ has not yet reached the manufacturer specified compliant level during a breath collection episode, a predicted value will be calculated. If $E_{E E O_{2}}$ is below $14 \%$, $\mathrm{CF}$ will be equal to 1 so $\mathrm{CFH}_{2} / \mathrm{CFCH}_{4}$ remain the same as the actual $\mathrm{H}_{2} / \mathrm{CH}_{4}$ measured. The relationship between $\mathrm{CF}$ and the $\mathrm{O}_{2}$ concentration in the breath sample is shown in Figure 2 .

The characteristics of the breath samples collected from 564 patients were analysed. The analysis has taken into account for the demographics, $E E \mathrm{O}_{2}$ and the end-expiratory hydrogen $\left(E E \mathrm{H}_{2}\right)$ and endexpiratory methane $\left(\mathrm{EECH}_{4}\right)$ concentrations. The data was analysed per patient. Typically, there were 5 samples collected for Glucose Breath Test and 6 samples collected for Lactose mal-digestion investigation.

A further 46 patients were studied in greater detail where extra hydrogen and methane readings were recorded when $\mathrm{O}_{2}$ was at $15 \%$, as well as $E E \mathrm{H}_{2}$ and ${ }_{E E C H} \mathrm{CH}_{4}$ values. This data was collected over a period of 12 weeks and it was analysed per breath sample.

In order to evaluate the efficacy of the CF, the diagnostic test result based on $E_{E E H}$ and $E_{E E C H}$ was compared with the predicted result using $\mathrm{CFH}_{2}$ and $\mathrm{CFCH}_{4}$.

\section{RESULTS}

The results indicated that an average of $95.4 \%$ of the 564 patients who had undergone the Combined $\mathrm{H}_{2} / \mathrm{CH}_{4}$ Breath Test (CBT) achieved ${ }_{E E O} \mathrm{O}_{2}$ below $14 \%$ (Table 1). There is no obvious difference between male and female, achieving $96.3 \%$ and $94.9 \%$ respectively. The result showed that none of the age 
medRxiv preprint doi: https://doi.org/10.1101/2020.10.22.20213876; this version posted February 23, 2021. The copyright holder for this preprint (which was not certified by peer review) is the author/funder, who has granted medRxiv a license to display the preprint in All rights reserved. No reuse allowed without permission.

groups between 20 - 80 years old had any difficulty delivering $E E O_{2}$ below $14 \%$ in their end-expiratory breath samples (Table 2). The $81-90$ years old group has an obvious reduction in delivering $\mathrm{EEO}_{2}$ below $14 \%$ but still achieves a $73.3 \%$ success rate.

For a further 46 patients, a total of 293 end-expiratory breath samples were analysed. The overall compliance rate is $88.1 \%$, with a breakdown between male and female of $96.6 \%$ and $82.4 \%$ respectively. This compliance rate is comparable to the larger data set. The percentage of individual breath samples which achieved $E_{E E O_{2}}$ below $14 \%$, arranged by gender and age group is shown in Figure 3. When comparing the compliance rate with their Body Mass Index (BMI), samples delivered by patients with a BMI between 15 and 10 reduced to $72.6 \%$, while samples from other BMI groups are all above $89 \%$, Figure 4 . There was no patient in the $36-40 \mathrm{BMI}$ group in this study.

The results showed a wide range of $E E O_{2}$, from the best sample of $9.5 \%$ to $16.2 \%$. The mean $E_{E E O_{2}}$ for the 293 samples is $12.9 \%$, with a standard deviation of 1.1. The $E_{E E} O_{2}$ data set also indicates a normal distribution, as shown in Figure 5.

In order to evaluate the efficacy of the correction factor (CF), the end-expiratory hydrogen $\left(E E \mathrm{H}_{2}\right)$ and end-expiratory methane $\left(\mathrm{EECH}_{4}\right)$ values were compared with the predicted hydrogen $\left(\mathrm{CFH}_{2}\right)$ and predicted methane $\left(\mathrm{CFCH}_{4}\right)$ values. The $\mathrm{CFH}_{2}$ and $\mathrm{CFCH}_{4}$ were calculated from the real-time $\mathrm{H}_{2}$ and $\mathrm{CH}_{4}$ measurement when the $\mathrm{O}_{2}$ concentration of the breath sample dropped to $15 \%$. CF at $15 \%$ oxygen is 1.19. The range of difference recorded was between $-30 \mathrm{ppm}$ and $114 \mathrm{ppm}$.

The difference in percentage between the actual and the predicted values for $\mathrm{H}_{2}$ and $\mathrm{CH}_{4}$ are shown in Figure $6 a$ and $6 \mathrm{~b}$ respectively. The results show the predicted values $\left(\mathrm{CFH}_{2}\right.$ and $\left.\mathrm{CFCH}_{4}\right)$ often underestimated the actual measurements $\left(E E \mathrm{H}_{2}\right.$ and $\left.E E \mathrm{CH}_{4}\right)$.

The overall average difference for hydrogen measurement using the correction factor was $-42.7 \%$, while the average percentage error for methane measurement using the correction factor was $7.8 \%$. However, it was noted that the percentage of error might be skewed when the measurement was at low level, e.g. $\mathrm{CFH}_{2}=\mathrm{O}$ and $E E \mathrm{H}_{2}=1$ will lead to $100 \%$ error. As the minimum threshold for positive result in $\mathrm{Gl}$ Breath Test is $10 \mathrm{ppm}$, the average error was adjusted by excluding any $\mathrm{EEH}_{2}$ below $10 \mathrm{ppm}$. The adjusted average errors for $\mathrm{CFH}_{2}$ and $\mathrm{CFCH}_{4}$ were $-36.4 \%$ and $-12.8 \%$ respectively.

In spite of the large discrepancy between the end-expiratory measurement and the predicted value, majority of the cases arrived at the same diagnosis regardless of using either $E_{E E} \mathrm{H}_{2} / \mathrm{EECH}_{4} \mathrm{Or} \mathrm{CFH}_{2} / \mathrm{CFCH}_{4}$. There was no false positive CBT result found in the 46 cases in this study.

However, the analysis has revealed that the predicted values $\left(\mathrm{CFH}_{2}\right.$ or $\left.\mathrm{CFCH}_{4}\right)$ in 4 out of 8 positive cases led to a false negative result. This indicates a diagnostic error of $50 \%$. Two such cases are shown in Figure 7a (Hydrogen false negative) and Figure 7b (Methane false negative) for a CBT (Glucose) test. They began with a high but stable baseline reading. Once glucose was administered, the ${ }_{E E} \mathrm{H}_{2}$ peaked within 20 minutes above the positive threshold. Both $E E H_{2}$ and $E E C H_{4}$ profiles indicated a typical glucose positive response. On the other hand, the predictive values $\left(\mathrm{CFH}_{2}\right.$ and $\left.\mathrm{CFCH}_{4}\right)$ were unable to correctly predict the end-expiratory measurement and failed to indicate a positive result. 
medRxiv preprint doi: https://doi.org/10.1101/2020.10.22.20213876; this version posted February 23, 2021. The copyright holder for this preprint (which was not certified by peer review) is the author/funder, who has granted medRxiv a license to display the preprint in All rights reserved. No reuse allowed without permission.

\section{DISCUSSION}

The diagnostic result of the CBT depends greatly on the quality of the breath sample collected. Although it is not the only factor, it must not be underestimated. For CBT with real-time measurement, quality of the end-expiratory breath is critical to the accuracy of the hydrogen and methane level.

The results indicated that the majority of patients who have undergone CBT with real-time measurement are able to deliver an end-expiratory breath sample. End-expiratory Oxygen $\left(E E O_{2}\right)$ measured in this study indicated that it was usually better than the recommended $14 \%$. The ability to deliver an end-expiratory breath was not affected by age, up to 80 years old, although there is an indication that the age group over 80 years old may have some difficulties. The compliance level did not appear to be affected by the patients' gender. In comparison, BMI can have a more profound effect on the patient's ability to deliver an end-expiratory breath sample.

Therefore, there is no obvious limitation or concern over the patient's ability to provide an endexpiratory breath sample. It is imperative special care is taken to collect the breath samples and to ensure that patient breathes out completely into the analyser.

The additional 46 patients in the second part of the study were randomly selected in a continuous period of 12 weeks. The proportion of positive cases in this period is $17.4 \%$. It is similar to the number of average positive cases over three years at the same centre, using the same breath analyser [16].

It was obvious from the analysis that $\mathrm{EEO}_{2}$ of the breath samples were not constant. In fact, it varied by a large degree, ranging from $16.2 \%$ to $9.5 \%$. Nevertheless, the manufacturer has pre-defined the ideal or target $E_{E} O_{2}$ at $14 \%$. The $\mathrm{CF}$ algorithm built into the $\mathrm{GastroCH}_{4} \mathrm{ECK}$ is similar to the method used in the carbon dioxide $\left(\mathrm{CO}_{2}\right)$ correction factor employed in gas chromatography breath analysers [12]. The published data indicated the end-tidal breath should ideally contain $5 \% \mathrm{CO}_{2}$ and suggested a specific correction factor algorithm which compensates for a range of $\mathrm{CO}_{2}$ levels between $2 \%-7 \%$. The $\mathrm{CF}$ from the GastroCH${ }_{4} \mathrm{ECK}$ only compensates oxygen level when the breath sample has an $\mathrm{EEO}_{2}$ level above $14 \%$.

This study indicated that setting $E_{E E O_{2}}$ at $14 \%$ is likely to be too high, as the mean $E_{E E O_{2}}$ in this study was $12.9 \%$. The rate of change in $\mathrm{H}_{2} / \mathrm{CH}_{4}$ values during an episode of breath sample collection will also significantly affect the validity of the $\mathrm{CF}$ and it expectedly varied to a large degree. Therefore, due to the highly inconsistent $E E O_{2}$ and the varying nature of the $\mathrm{H}_{2} / \mathrm{CH}_{4}$ in an episode of breath sample collection, the resulting $\mathrm{CFH}_{2} / \mathrm{CFCH}_{4}$ value based on ${ }_{\mathrm{EEO}} \mathrm{O}_{2}$ above $14 \%$ is often unreliable. Therefore, it is indeed possible to produce a false negative result if $\mathrm{CFH}_{2} / \mathrm{CFCH}_{4}$ is used.

As shown in this study, CF can contribute a level of uncertainty. When there is an operator who can ensure the quality of the breath sample during a real-time breath sample collection episode, CF may be redundant in real-time GI breath measurement.

On the other hand, $\mathrm{O}_{2}$ measurement is essential as a quality indicator for the breath sample. The continuous real-time trace of oxygen concentration on the GastroCH ${ }_{4} \mathrm{ECK}$ Gastrolyzer (Version 1) prevents the patient from accidentally breathing in during an episode of breath sample collection. Should secondary breathing be detected, the collection process can be aborted and re-started. This oxygen sensing feature ensures the quality of the breath sample by significantly reducing the uncertainties that arise from the sample collection stage and further exploiting the benefits of realtime breath measurement.

It may be important to note this study has focused on real-time breath measurement. Characteristics of $\mathrm{O}_{2}$ with a bag collection system are likely to be different and may require further study. In addition, 
medRxiv preprint doi: https://doi.org/10.1101/2020.10.22.20213876; this version posted February 23, 2021. The copyright holder for this preprint (which was not certified by peer review) is the author/funder, who has granted medRxiv a license to display the preprint in

All rights reserved. No reuse allowed without permission.

the breath holding time has a significant effect to the mixture of gases in the end-expiratory breath [17]. Hence, breath sampling procedure must be designed to avoid the confusion between genuine maximum exhalation and the sensation of dyspnoea due to excessive breath hold.

\section{CONCLUSION}

The majority of patients in this study were able to deliver breath samples below $14 \% \mathrm{O}_{2}$. Oxygen concentration of an end-expiratory breath sample is largely unpredictable. The CF algorithm build-in to $\mathrm{GastroCH} \mathrm{CH}_{4} \mathrm{ECK}$ proved to be unreliable and led to a diagnostic error of $50 \%$ of the positive cases in this study. Hence, with such uncertainty for the predicted $\mathrm{H}_{2} / \mathrm{CH}_{4}$ values, it is essential that the actual end-expiratory breath is collected and CF may be redundant in real-time CBT. On the contrary, the onscreen continuous oxygen trace is highly valuable to ensure the quality of the end-expiratory breath sample collection.

\section{REFERENCES}

[1] Saad R J, Chey W D; Breath Tests for gastrointestinal disease: the real deal or just a lot of hot air?; Gastroenterology; 2007 Dec; 133(6): 1763-6. doi: 10.1053/j.gastro.2007.10.059

[2] Simrén M and Stotzer P-O; Use and abuse of hydrogen breath tests; Gut 2006 Mar; 55(3): 297303. Doi: 10.1136/gut.2005.075127

[3] Rezaie A, Buresi M, Lembo A, Lin H, McCallum R, Rao S, Schmulson M, VAldovinos M, Zakko S, Pimentel M; Hydrogen and Methane-Based Breath Testing in Gastrointestinal Disorders: The North American Consensus; Am J Gastroenterol; 2017; 112:775-784; doi: 10.1038/ajg.2017.46

[4] Gasbarrini A et al; Methodology and indications of H2-Breath testing in gastrointestinal diseases: the Rome Consensus Conference; Aliment Pharmacol Ther; 2009; 29 Suppl 1:1-49. doi: 10.1111/j.1365-2036.2009.03951.x

[5] Ghoshal U C; How to Interpret Hydrogen Breath Tests; J Neurogastroenterol Motil. 2011 Jul; 17(3): 312-317. doi: 10.5056/jnm.2011.17.3.312

[6] Robb T A, Davidson G P; Advances in breath hydrogen quantitation in paediatrics: Sample collection and normalisation to constant oxygen and nitrogen levels; Clin. Chim. Acta; 1981; 111:281-5

[7] Hamilton L H; Breath Tests \& Gastroenterology, Second Edition 1998.

[8] Lee W S, Davidson G P, Moore D J, Butler R N; Analysis of the breath hydrogen test for carbohydrate malabsorption: Validation of a pocket-sized breath test analyser; J. Paediatr. Child Health; 2000; 36:340-342

[9] Anderson J, Hlastala M P; Breath tests and airway gas exchange; Pulm Pharmacol Ther. 2007; 20(2):112-7 doi: 10.1016/j.pupt.2005.12.002

[10] Fleming S C; Evaluation of a hand-held hydrogen monitor in the diagnosis of intestinal lactase deficiency; Ann Clin Biochem; 1990: 27:499-500 
medRxiv preprint doi: https://doi.org/10.1101/2020.10.22.20213876; this version posted February 23, 2021. The copyright holder for this preprint (which was not certified by peer review) is the author/funder, who has granted medRxiv a license to display the preprint in

perpetuity.
All rights reserved. No reuse allowed without permission.

[11] de Lacy Costello B P J, Ledochowski M, Ratcliffe N M; The importance of methane breath testing: a review; J. Breath Res. 7; 2013 024001; doi: 10.1088/1752-7155/7/2/024001

[12] Niu H C, Schoeller D and Klein P. Improved gas chromatographic quantitation of breath hydrogen by normalization to respiratory carbon dioxide. J Lab Clin Med 1979; 94:755-63.

[13] Wolfson M R; Shaffer T H; Cardiopulmonary Physical Therapy (Fourth Edition), 2004 - 02 14\%

[14] Wagner P D; The physiological basis of pulmonary gas exchange: implications for clinical interpretation of arterial blood gases; European Respiratory Journal; 2015; 45:227-243

[15] GastroCH $\mathrm{CH}_{4} \mathrm{ECK}$ user manual (2014) Bedfont Scientific Ltd. UK

[16] Materacki L, Lee SM, Laidler P, Yong K, Betteridge F, Murugiah D, Colleypriest B; Is methane testing a useful adjunct to hydrogen breath testing?; BSG Annual Meeting 2018, Liverpool, UK, $4^{\text {th }}-7^{\text {th }}$ June, 2018

[17] Levitt M D, Ellis C, Furne J; Influence of method of alveolar air collection on results of breath tests; Dig. Dis. Sci. 1998 Sep; 43(9):1938-45. doi:10.1023/a:1018874223418 


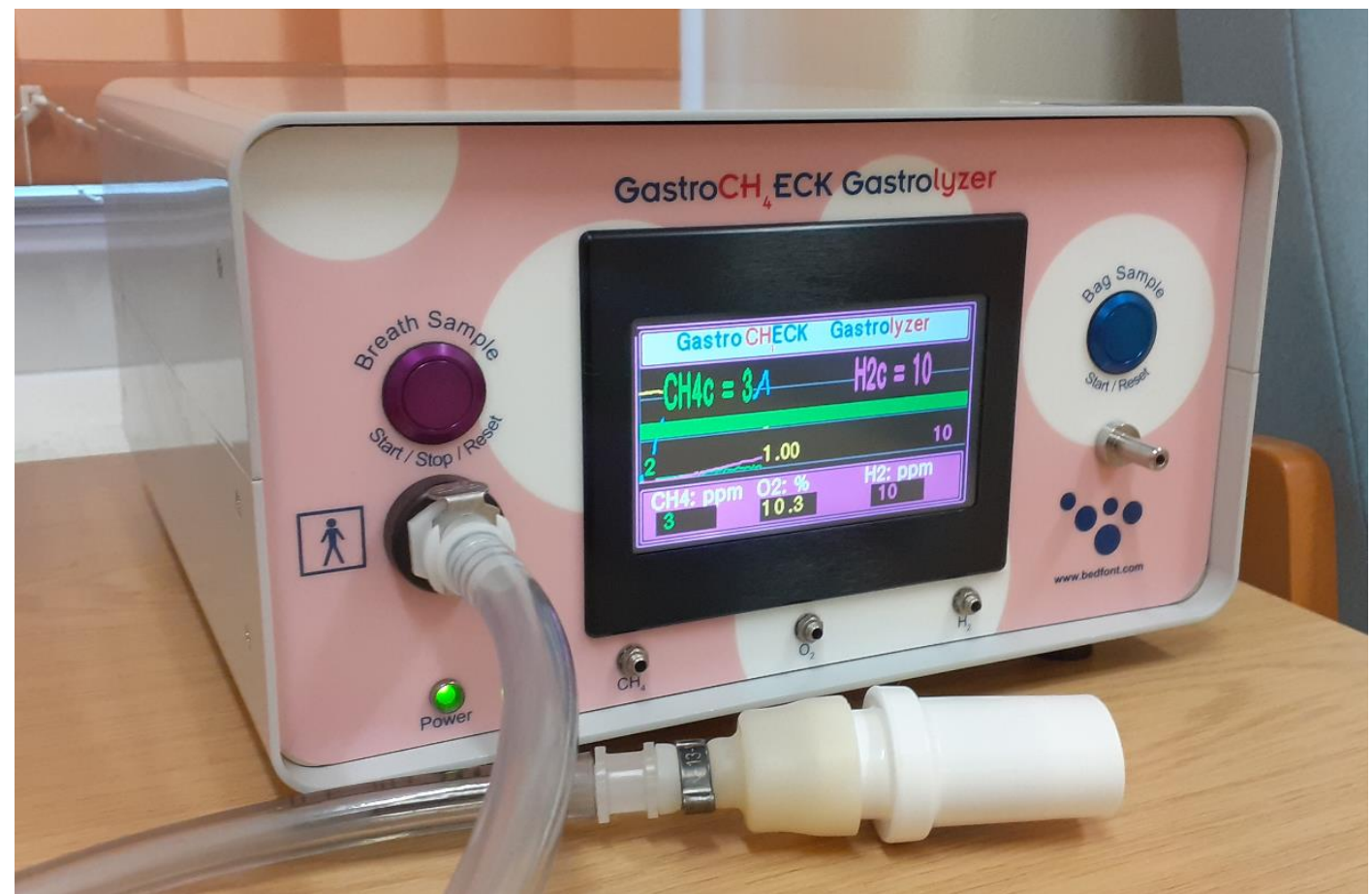

Figure 1: Real-time breath measurement setup on GastroCH ${ }_{4} E C K$ Gastrolyzer (Ver. 1), software version: V11.0, manufactured by Bedfont Scientific Ltd. UK.

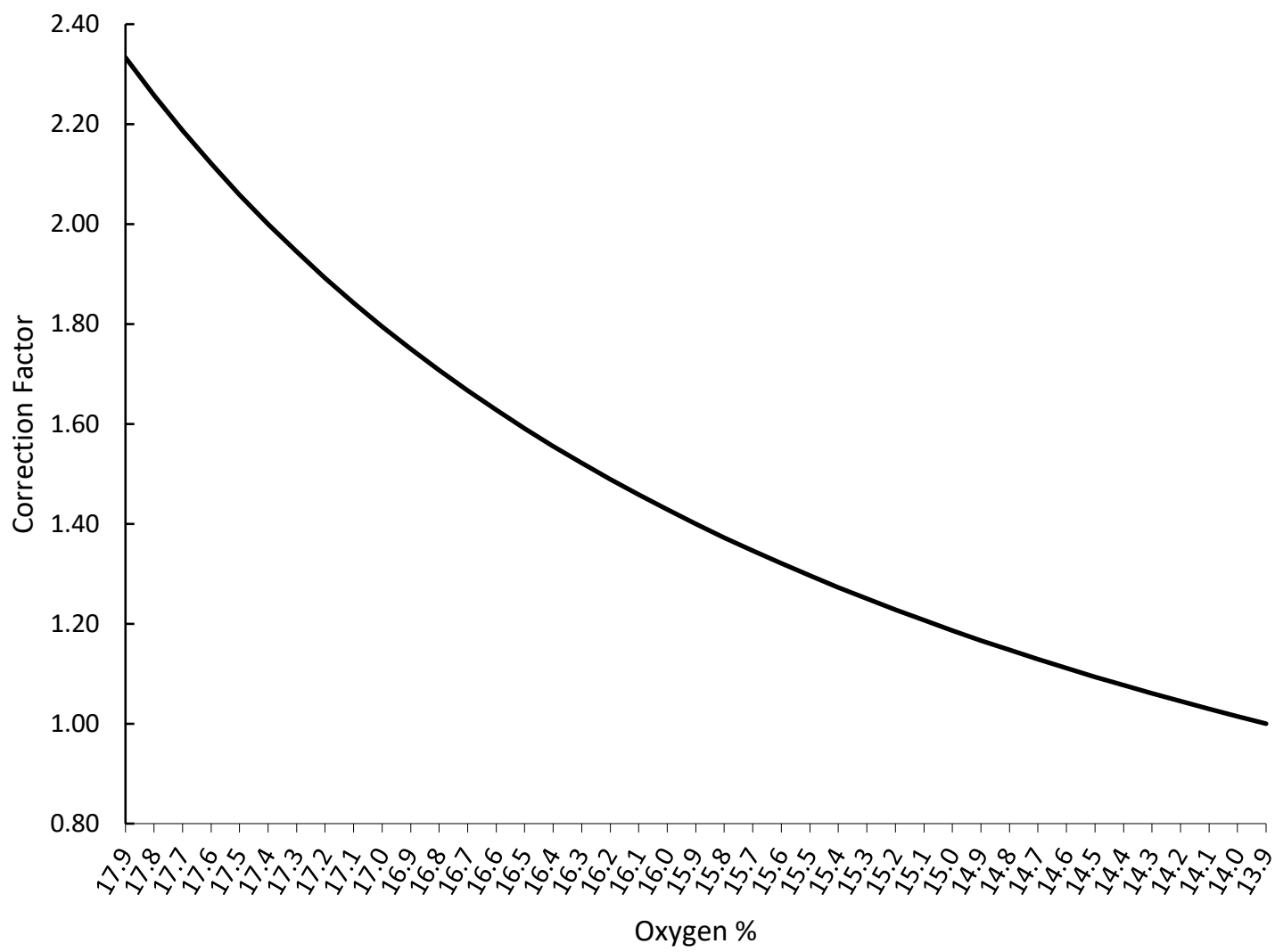

Figure 2: Correction Factor (CF), in $\mathrm{GastroCH}{ }_{4} \mathrm{ECK}$, in relation to the percentage of oxygen in breath sample. The CF value is 1 when oxygen level is below 13.9. 
medRxiv preprint doi: https://doi.org/10.1101/2020.10.22.20213876; this version posted February 23, 2021. The copyright holder for this preprint (which was not certified by peer review) is the author/funder, who has granted medRxiv a license to display the preprint in

All rights reserved. No reuse allowed without permission.

Table 1: The demographic of the patients who were able to deliver $E E O_{2}$ below $14 \%$

\begin{tabular}{llllll}
\hline & $\begin{array}{l}\text { No. of } \\
\text { Patients }\end{array}$ & $\begin{array}{l}\text { No. of patients } \\
\text { below } 14 \% \mathrm{O}_{2}\end{array}$ & $\begin{array}{l}\text { \% of patients } \\
\text { below } 14 \% \mathrm{O}_{2}\end{array}$ & $\begin{array}{l}\text { No. of patients } \\
\text { above } 14 \% \mathrm{O}_{2}\end{array}$ & $\begin{array}{l}\% \text { of patients } \\
\text { above } 14 \% \mathrm{O}_{2}\end{array}$ \\
\hline Male & 191 & 184 & 96.3 & 7 & 3.7 \\
Female & 373 & 354 & 94.9 & 19 & 5.1 \\
Total & 564 & 538 & 95.4 & 26 & 4.6 \\
\hline
\end{tabular}

Table 2: The distribution of patients who were able to deliver $\mathrm{EEO}_{2}$ below $14 \%$ by age group

\begin{tabular}{|c|c|c|c|c|c|c|c|}
\hline \multirow[b]{2}{*}{$\begin{array}{l}\text { Age } \\
\text { group }\end{array}$} & \multirow[b]{2}{*}{$\begin{array}{l}\text { No. of } \\
\text { patients }\end{array}$} & \multirow[b]{2}{*}{$\begin{array}{l}\text { No. of } \\
\text { patients } \\
\text { below } \\
14 \% \mathrm{O}_{2}\end{array}$} & \multirow[b]{2}{*}{$\begin{array}{l}\% \text { of } \\
\text { patients } \\
\text { below } 14 \% \\
\mathrm{O}_{2}\end{array}$} & \multicolumn{2}{|c|}{ Male } & \multicolumn{2}{|c|}{ Female } \\
\hline & & & & $\begin{array}{l}\text { No. of } \\
\text { patients } \\
\text { below } \\
14 \% \mathrm{O}_{2}\end{array}$ & $\begin{array}{l}\% \text { of } \\
\text { patients } \\
\text { below } 14 \% \\
\mathrm{O}_{2}\end{array}$ & $\begin{array}{l}\text { No. of } \\
\text { patients } \\
\text { below } \\
14 \% \mathrm{O}_{2}\end{array}$ & $\begin{array}{l}\% \text { of } \\
\text { patients } \\
\text { below } 14 \% \\
\mathrm{O}_{2}\end{array}$ \\
\hline $11-20$ & 19 & 17 & 89.5 & 7 & 100 & 10 & 83.3 \\
\hline $21-30$ & 76 & 73 & 96.1 & 24 & 100 & 49 & 94.2 \\
\hline $31-40$ & 74 & 74 & 100 & 26 & 100 & 48 & 100 \\
\hline $41-50$ & 87 & 83 & 95.4 & 31 & 93.5 & 52 & 96.3 \\
\hline $51-60$ & 118 & 112 & 94.9 & 28 & 96.6 & 84 & 94.4 \\
\hline $61-70$ & 99 & 97 & 98.0 & 36 & 94.7 & 61 & 100 \\
\hline $71-80$ & 76 & 71 & 88.2 & 27 & 96.4 & 44 & 91.7 \\
\hline $81-90$ & 15 & 11 & 73.3 & 5 & 83.3 & 6 & 66.7 \\
\hline Total & 564 & 538 & 95.4 & 189 & 96.3 & 373 & 94.9 \\
\hline
\end{tabular}


medRxiv preprint doi: https://doi.org/10.1101/2020.10.22.20213876; this version posted February 23, 2021. The copyright holder for this preprint (which was not certified by peer review) is the author/funder, who has granted medRxiv a license to display the preprint in All rights reserved. No reuse allowed without permission.

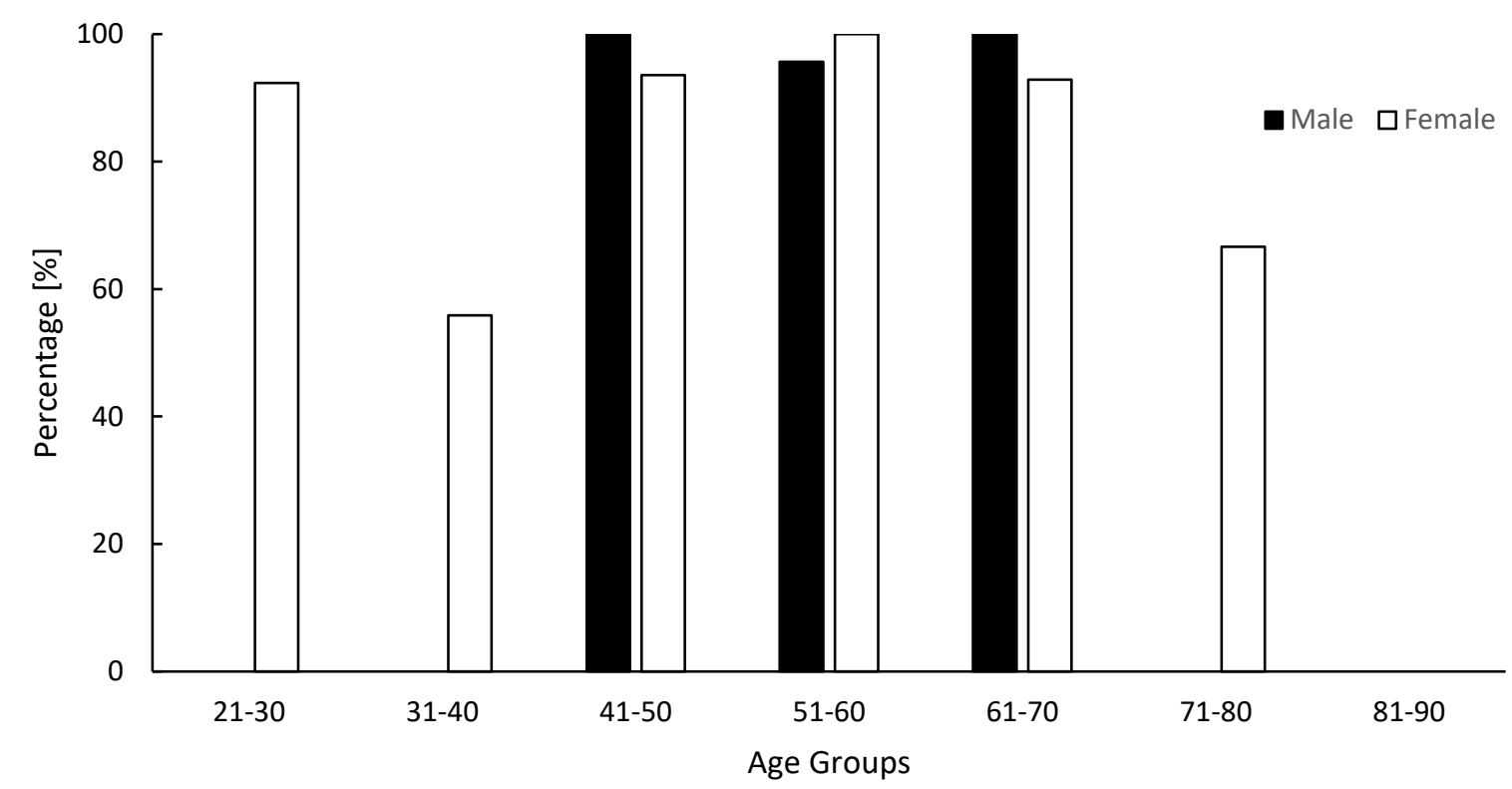

Figure 3: The percentage of individual breath samples which achieved ${ }_{E E} \mathrm{O}_{2}$ below $14 \%$ by gender and age group

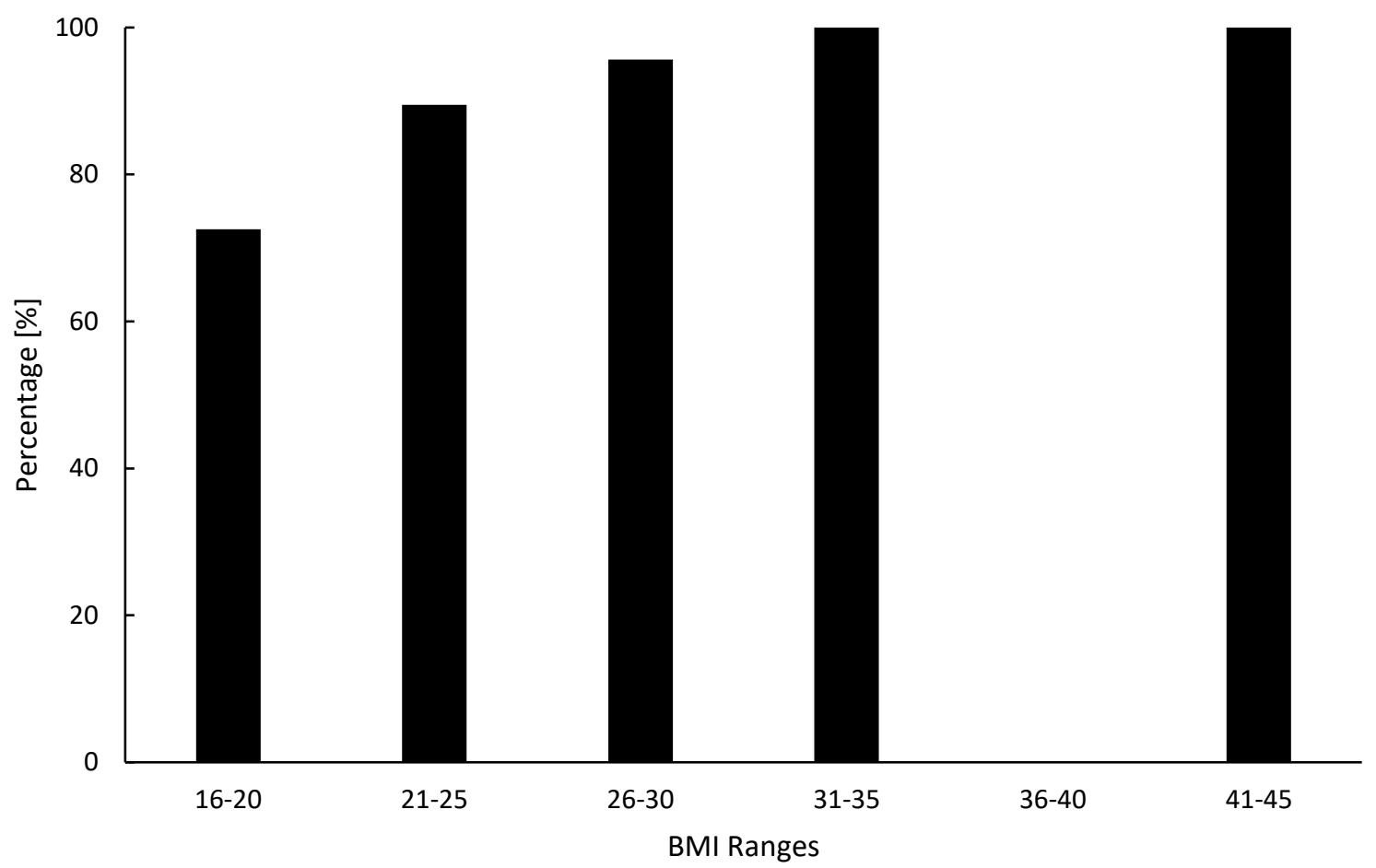

Figure 4: The percentage of individual breath samples which achieved $E E O_{2}$ below $14 \%$ by patient's $\mathrm{BMI}$. (Note: there was no patient in the data group of BMI 36-40 in this study) 


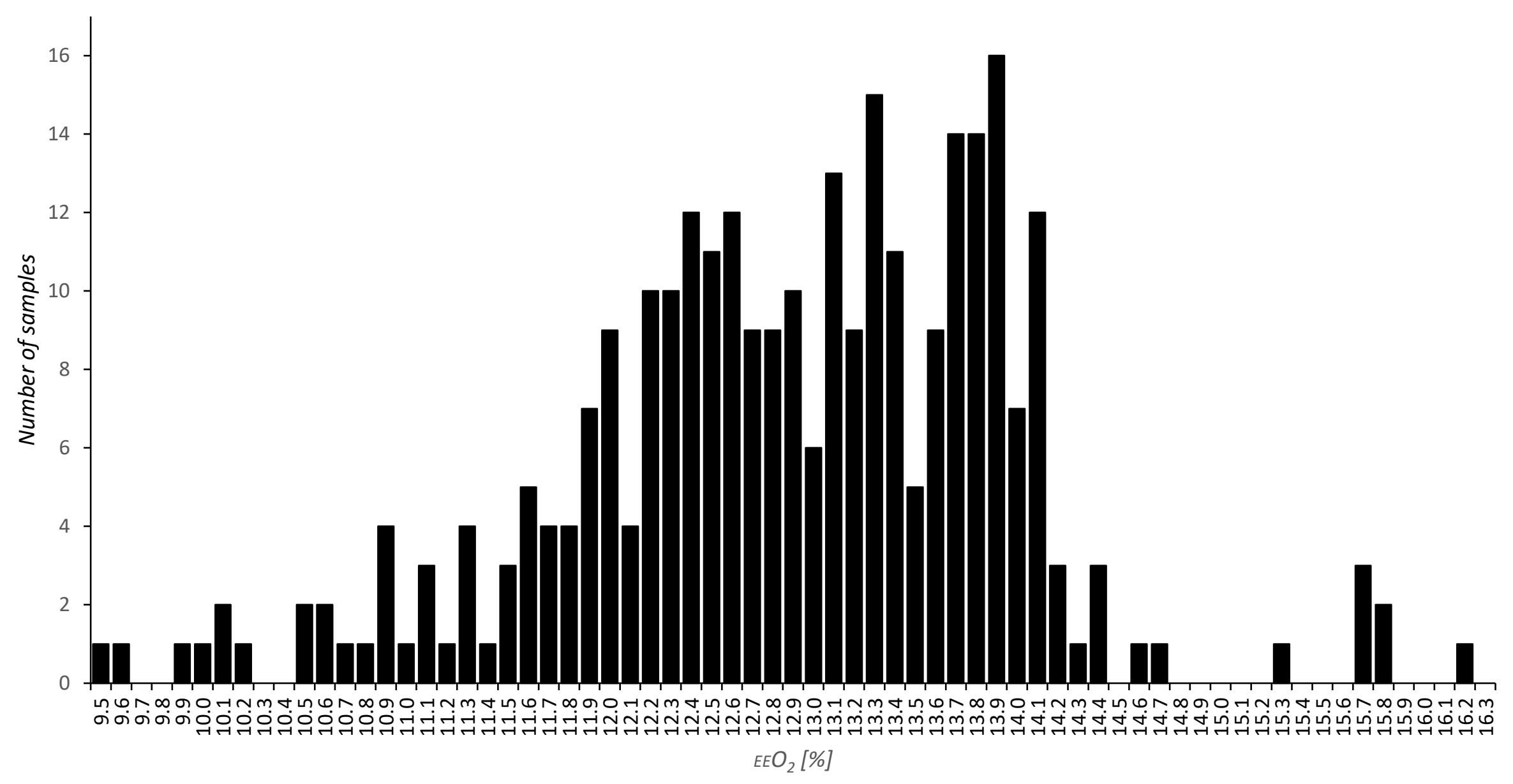

Figure 5: The distribution of $E_{E E O_{2}}$ in end-expiratory breath samples 
medRxiv preprint doi: https://doi.org/10.1101/2020.10.22.20213876; this version posted February 23, 2021. The copyright holder for this preprint (which was not certified by peer review) is the author/funder, who has granted medRxiv a license to display the preprint in

perpetuity.
All rights reserved. No reuse allowed without permission.

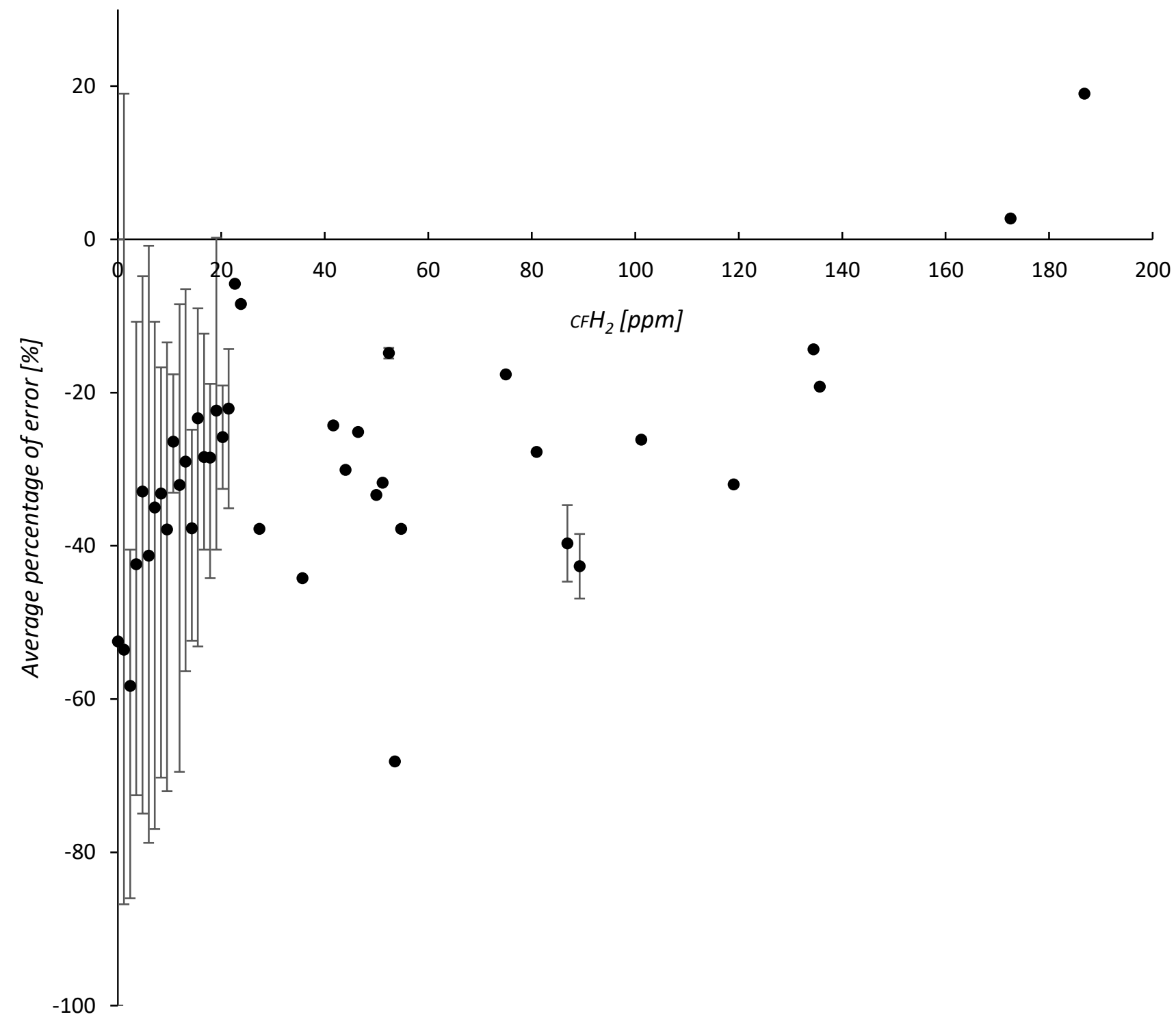

Figure 6a: Percentage of error for $\mathrm{CFH}_{2}$ compared to $\mathrm{EEH}_{2}$. 
medRxiv preprint doi: https://doi.org/10.1101/2020.10.22.20213876; this version posted February 23, 2021. The copyright holder for this preprint (which was not certified by peer review) is the author/funder, who has granted medRxiv a license to display the preprint in

All rights reserved. No reuse allowed without permission.

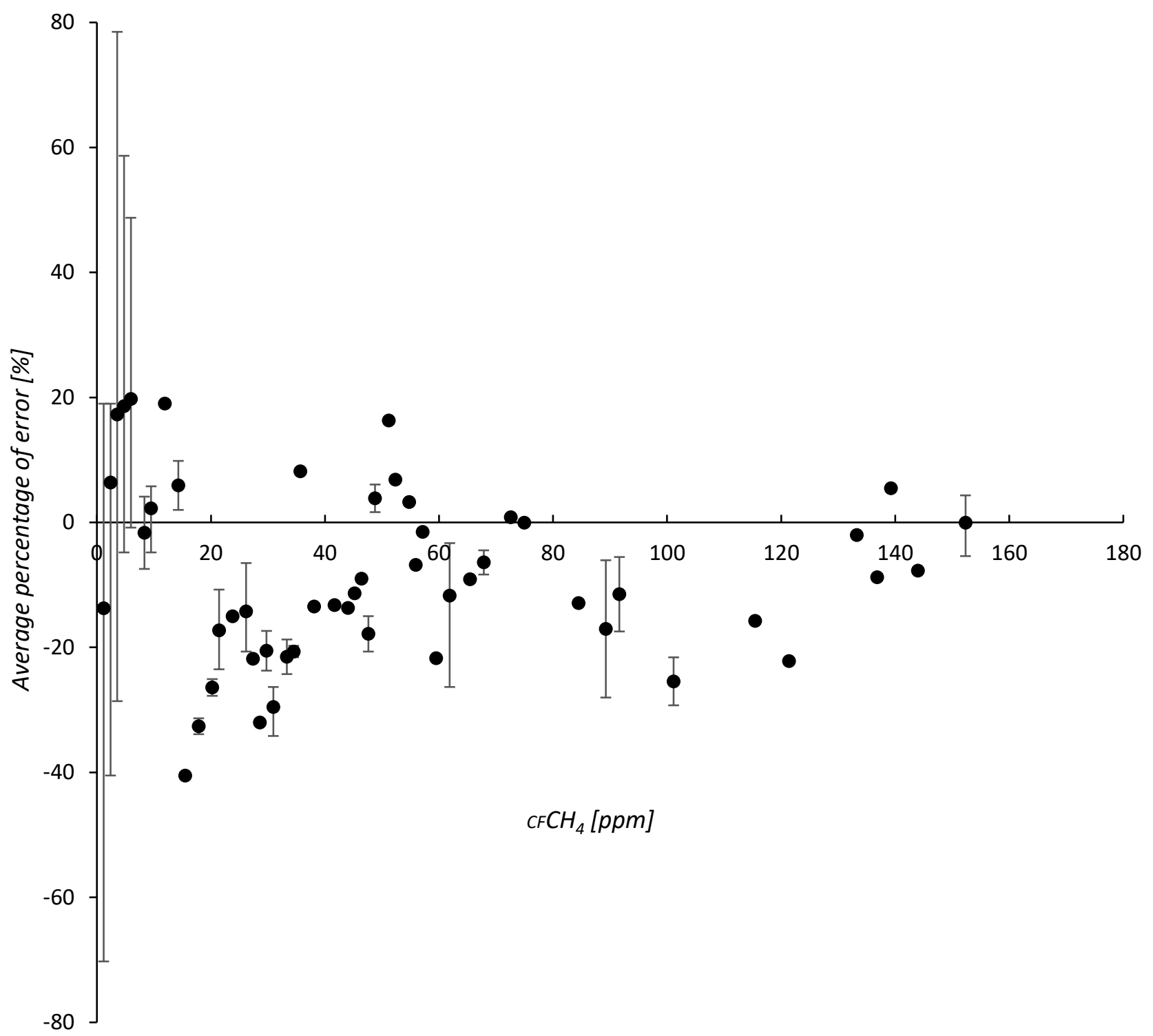

Figure 6b: Percentage of error for $\mathrm{CFCH}_{4}$ compared to ${ }_{E E C H}$. 
medRxiv preprint doi: https://doi.org/10.1101/2020.10.22.20213876; this version posted February 23, 2021. The copyright holder for this preprint (which was not certified by peer review) is the author/funder, who has granted medRxiv a license to display the preprint in

perpetuity.
All rights reserved. No reuse allowed without permission.

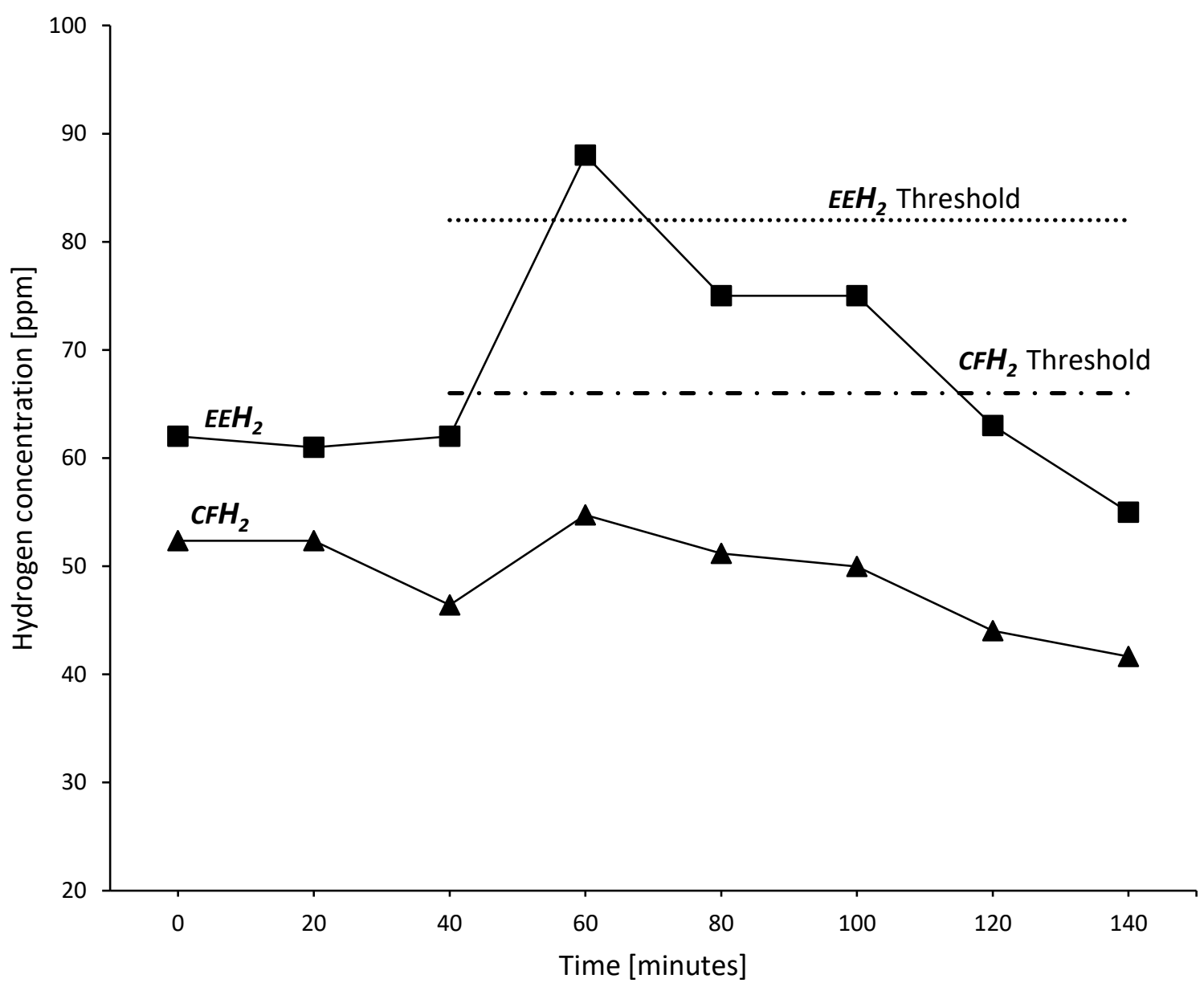

Figure 7a: Difference between $\mathrm{EEH}_{2}$ and $\mathrm{CFH}_{2}$ values in a GI Breath Test (Glucose) 
medRxiv preprint doi: https://doi.org/10.1101/2020.10.22.20213876; this version posted February 23, 2021. The copyright holder for this preprint (which was not certified by peer review) is the author/funder, who has granted medRxiv a license to display the preprint in perpetuity.

All rights reserved. No reuse allowed without permission.

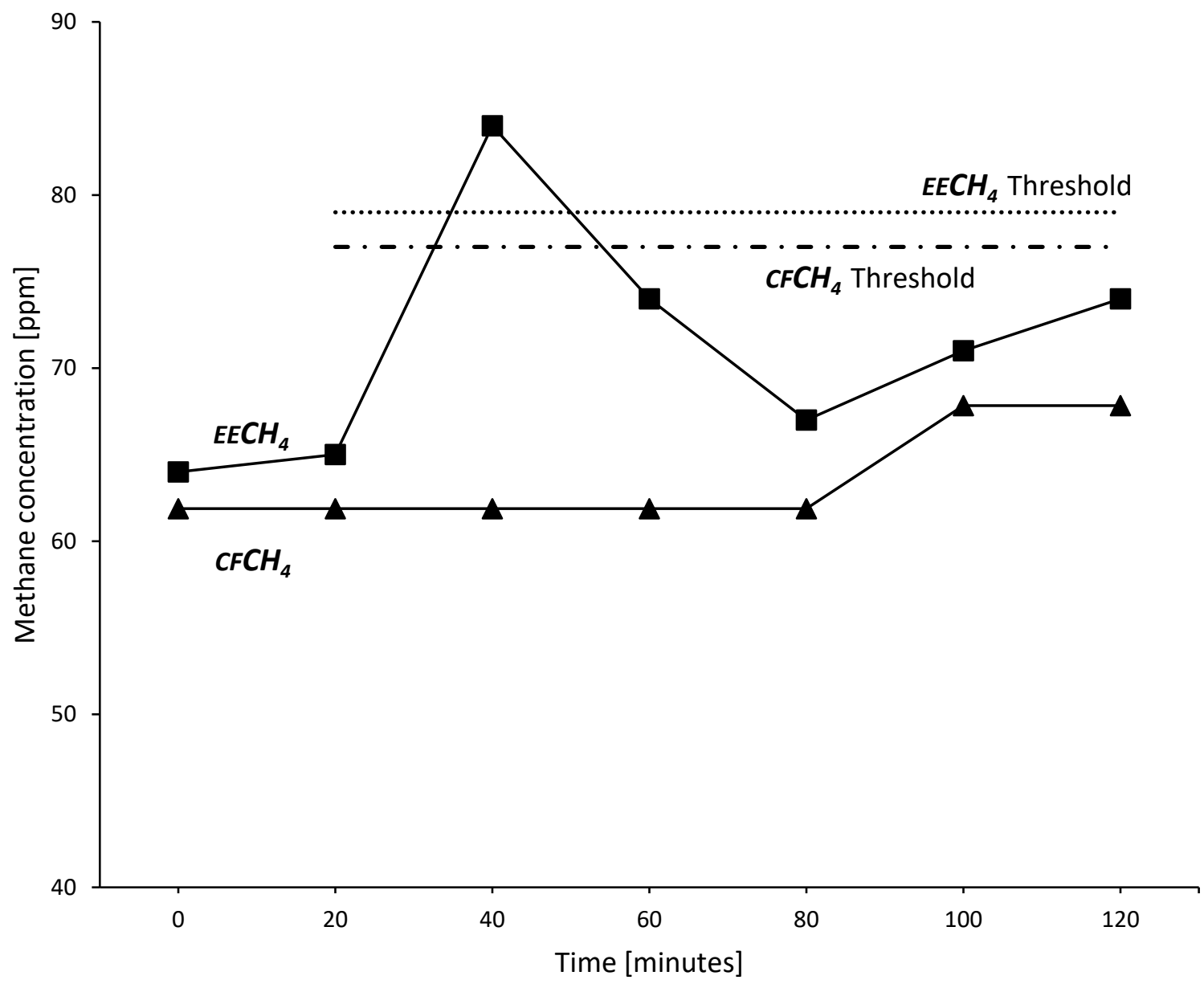

Figure 7b: Difference between $\mathrm{EECH}_{4}$ and $\mathrm{CFCH}_{4}$ values in a GI Breath Test (Glucose) 